\title{
Study the Effect of Gum Arabic and Triton X-100 on Stability and Thermal Conductivity of ZnO/ethylene glycol Nanofluids
}

\author{
NOOR SABEEH MAJEED ${ }^{1}$, HUSSEIN A. ALABDLY ${ }^{2}$, \\ HUSSAM NADUM ABDALRAHEEM AL ANI ${ }^{3}$, DUMITRU PASCU ${ }^{4}$, \\ AURELIA CRISTINA NECHIFOR ${ }^{*}$ \\ ${ }^{1}$ Chemical Industries Department, Institute of Technology-Baghdad, Middle Technical University, Baghdad, Iraq \\ ${ }^{2}$ Al-Nahrain University, Department of Chemical Engineering, Baghdad-Iraq \\ ${ }^{3}$ Chemical Industries Department, Institute of Technology-Baghdad, Middle Technical University, Baghdad, Iraq \\ ${ }^{4}$ Politehnica University of Bucharest, Department of Analytical Chemistry and Environmental Engineering, 1-7 Gheorghe \\ Polizu Str., 011061, Bucharest, Romania
}

\begin{abstract}
Stability of nanofluids is one of the most important factors to ensure the most benefit of the properties of nanoparticles. Zinc oxide was used in the research with concentration between (0.2-1) wt. $\%$ with ethylene glycol base fluid. The stability of $\mathrm{ZnO}$ nanofluid was enhanced by adding two types of surfactants Tx-100 and Gum Arabic with concentration of (0.1-0.5) vol. \% to stabilize the ZnO nanoparticles in the base fluid. The results showed that the Gum Arabic surfactant led to more stable fluid than that of TX-100; this was shown from zeta potential and UV spectroscopy measurements. The thermal conductivity coefficient was also measured, and the results showed that the thermal conductivity increased with adding surfactant than without using a stabilizer.
\end{abstract}

Keywords: ZnO/ethylene glycol nanofluids, stability, Tx-100 surfactant, Gum Arabic, thermal conductivity

\section{Introduction}

Energy can be saved in different ways engineering operations. The need to enhance heat transfer of fluids has led the use of solid particles suspension as one of the most important methods because of their high thermal conductivity. However, these particles have few behavior problems such as sedimentation, fouling and pressure drop increment. There are many techniques used to overcome them and to increase the stability of these particles in many different base fluids. Different materials are used as solid particles suspended into the fluids, like metals ( $\mathrm{Al}, \mathrm{Cu}, \mathrm{Au}$, Fe, etc), oxides $\left(\mathrm{Al}_{2} \mathrm{O}_{3}, \mathrm{TiO}_{2}, \mathrm{CuO}, \mathrm{SiO}_{2}, \mathrm{Fe}_{2} \mathrm{O}_{3}\right)$, and different chemical compounds ( $\mathrm{AIN}, \mathrm{CaCO}_{3}, \mathrm{SiC}$, graphene, etc). These particles are suspended in traditional solvents fluid like water, ethylene glycol, engine oil, propylene glycol and more. The nanoparticles need to have a large surface area, but the flow of such suspension through a narrowed channel (constricted channel) may become intermittent and may led even to clogging. Therefore, the nanofluid must be able to avoid this in the flowing and to increase thermal conductivity. Two - step method included the suspension of nanoparticles into the base fluids by employing various mechanical, physical and chemical mechanisms. Xie et al. [1] used such two-step methods to prepare $\mathrm{Al}_{2} \mathrm{O}_{3}$ with propylene glycol and ethylene glycol base fluids. The $\mathrm{TiO}_{2} /$ water nanofluid was prepared by Murshed et al. [2]. The advantage of the method used to prepare nanofluids is that the nanoparticles have the ability to agglomerate during time due to high surface activity. Many studies were focused to about the different ways to increase the stability of nanofluids, including finding the optimum $p \mathrm{H}$ range, dispersal materials, and surfactants, shear mixing and ultra-sonic agitation. Different studies confirmed that the changing of $\mathrm{pH}$ meter or using different concentration to each the dispersants and nanoparticles in the base fluids. This is indicated to enhance the stability of nanofluids, which also affected to their property like, thermal conductivity and viscosity [3-8]. Hwang et al. [9] have used two types of nanoparticles carbon black and silver, suspended in water and silicon- oil base fluid respectively. By adding SDS (Sodium Dodecyl Sulfate) as a surfactant with $1 \mathrm{wt}$ \% concentration, these prepared nanofluids showed

*email: aureliacristinanechifor@gmail.com 
the stability during 60 days. The semiconductor materials with great advantages were employed in many applications in optoelectronic devices, photo catalysts, cosmetics, pigments, ceramics, solar cells and sensors [10, 11]. Chaudhuri and Paria [12] used sulfur nanoparticles in base fluid and added different surfactants to analyze the suspension stability. Other authors [13] applied UV- visible spectroscopy to study to study the stability of $\mathrm{TiO}_{2}$ nanoparticles in base fluid with different surfactants. Zaid et al. [14] investigated the effect of SDS surfactant on recovered oil with two types of nanoparticles $\mathrm{ZnO}$ and $\mathrm{Al}_{2} \mathrm{O}_{3}$. Also, we mention the researches of Anand and Siby [15] about the effect of four different surfactants (Triton Tx-100, polyethylene glycol (PEG 6000), cetyltrimethylammonium bromide (CTAB), SDS) added into a zinc oxide / water base fluid. Irwan et al. [16] have used Gum Arabic as surfactant to study the stability of $\mathrm{Al}_{2} \mathrm{O}_{3} /$ water nanofluid.

\section{Materials and methods}

\subsection{Materials}

Zinc oxide nanoparticles (Aladdin Reagents Company, Shanghai, Chania) are used in this paper. There are two types of surfactants is added into nanofluids Tx-100 (Beijing GH Trading Co., ltd.) and Gum Arabic (Guangzhou Zio Chemical Co., ltd.) with ethylene glycol as solvent.

\subsection{Preparation of Nanofluid}

Zinc oxide nanoparticles are in the form of white powder with particle sizes of $5 \mathrm{~nm}$. The $\mathrm{ZnO}$ nanoparticles are added to the ethylene glycol base fluid at different weight fraction (0.2-1) wt. \%. The surfactant is added into the $\mathrm{ZnO} /$ ethylene glycol at different concentration (0.1-0.5) vol. \%. The nanofluids prepared by mixing the solid nanoparticles with ethylene glycol using $400 \mathrm{rpm}$ stirring. Then the nanofluids are stabilized by sonication (MTI Corporation made in USA, equipment) for 30 min to obtain a good stability of nanofluid prepared.

\subsection{Characterization Measurements}

Zeta potential of $\mathrm{ZnO} /$ ethylene glycol without/with surfactant nanofluids was determined by using equipment (Zeta plus USA made). UV-vis spectrometer type (Shimadzu UV-160) and a thermal property analyzer KD2 Pro (Decagon Device Corp., Pullman) were also used to measure the light absorbance and thermal conductivity, respectively. All the characterization measurements were performed at room temperature.

\section{Results and discussions}

\subsection{Zeta potential}

Measuring the zeta potential of nanofluids with two types of surfactants Tx-100 and Gum Arabic (GA) is one of the most important method to study the mechanism of stability of $\mathrm{ZnO}$ / ethylene glycol nanofluid. The zeta potential is measured during 60 days for different concentrations between (0.1- 0.5) wt. \% for Tx-100 and Arabic Gum. Figure 1 shows the stability (expressed by values of zeta potential) of $\mathrm{ZnO} /$ ethylene glycol nanofluids without stabilizer. The results reveal that the nanofluid with less concentration of stability of $\mathrm{ZnO}$ is much more stable than the samples with high concentration of $\mathrm{ZnO}$ in the base fluid. This is happened due to the mechanism of Brownian motion at high concentration the when the $\mathrm{ZnO}$ nanoparticles tend to agglomerate and they are settled after short time, in agreement with Irwan et al. [16]. 


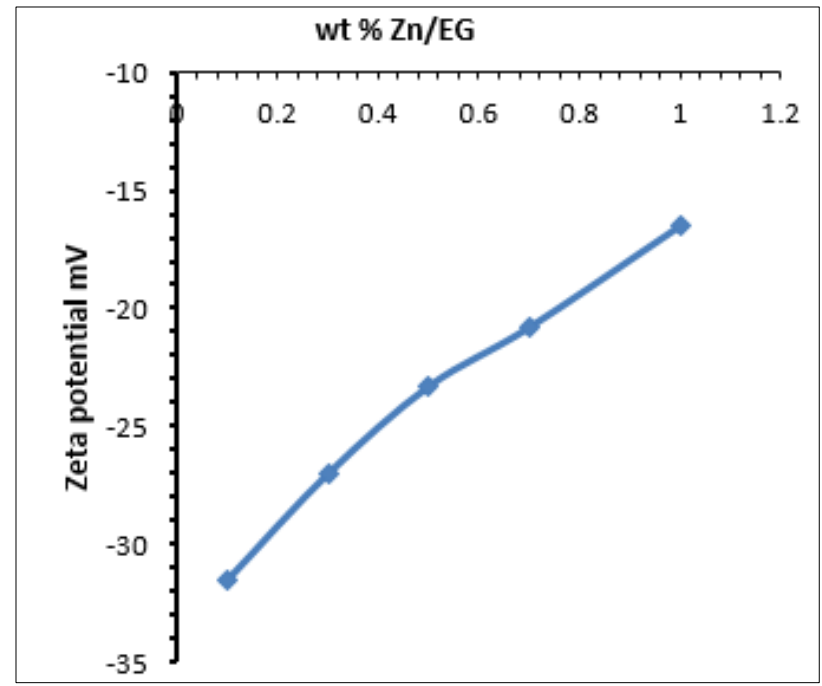

Figure 1. Zeta potential values $\mathrm{ZnO} /$ ethylene glycol nanofluids without surfactants at different concentrations

Figure 2 shows that values of zeta potential at different surfactants concentrations (0.1-0.5) wt. \%. The obtained values are in the range of -30 to $-40 \mathrm{mV}$ for $\mathrm{Tx}-100$ and in the range of -48 to $-55 \mathrm{mV}$ for GA. It is known that nanofluids are considered stable if the zeta potential ranges between (40-60) $\mathrm{mV}$ (either negative or positive values). Our results show therefore a higher stability for mixture with Gum Arabic (GA) than with Tx-100 for the same concentrations. We interpreted the fact that the Gum Arabic leads to a higher stability than Tx gum because of its ability to minimize the interactions between $\mathrm{ZnO}$ nanoparticles, as also stated by Pauzi et al. [17].

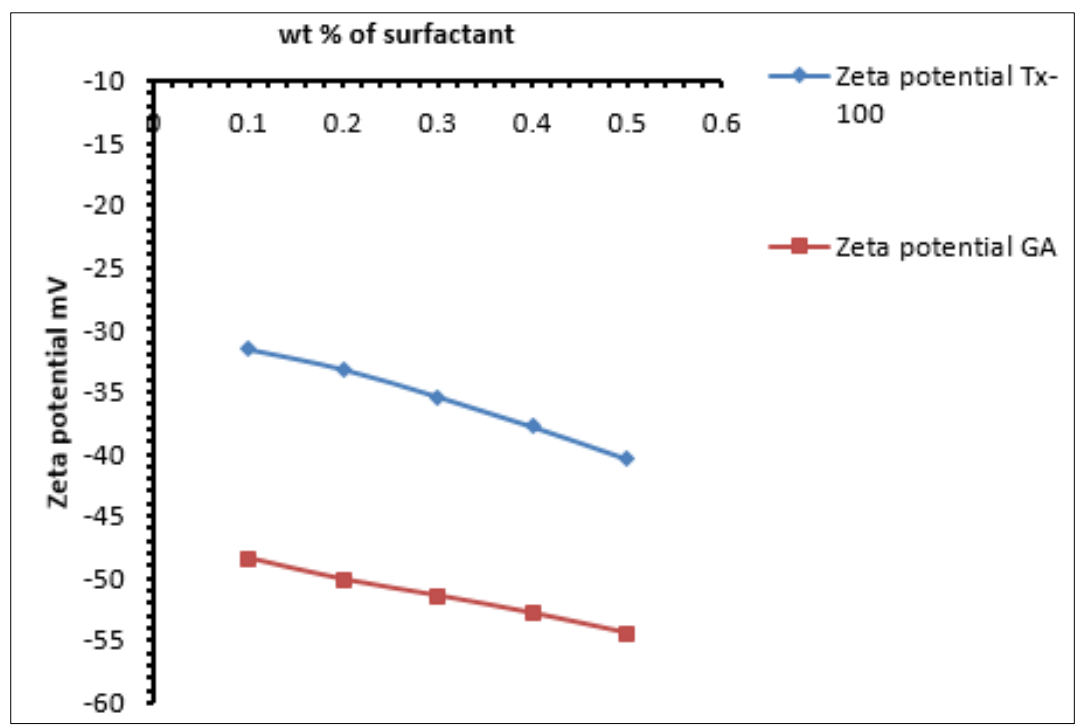

Figure 2. Zeta potential values of $\mathrm{ZnO}$ containing nanofluids with Gum Arabic and Tx-100 addition for different concentrations

\subsection{UV-Vis spectrophotometry}

The stability of prepared nanofluids $\mathrm{ZnO}$ / ethylene glycol containing surfactants can also be simply illustrated by the absorbance of light using UV-Vis spectrophotometry just after their preparation. Figure 3 shows that the wavelength of absorption peaks for just prepared $\mathrm{ZnO}$ /ethylene glycol with GA and Tx at constant concentration of $0.5 \mathrm{vol} \%$ is $370 \mathrm{~nm}$ and $335 \mathrm{~nm}$, respectively, this being in agreement with the standard value of $\mathrm{ZnO}$ nanofluids as reported by Estrada-Urbina et al. [18]. 


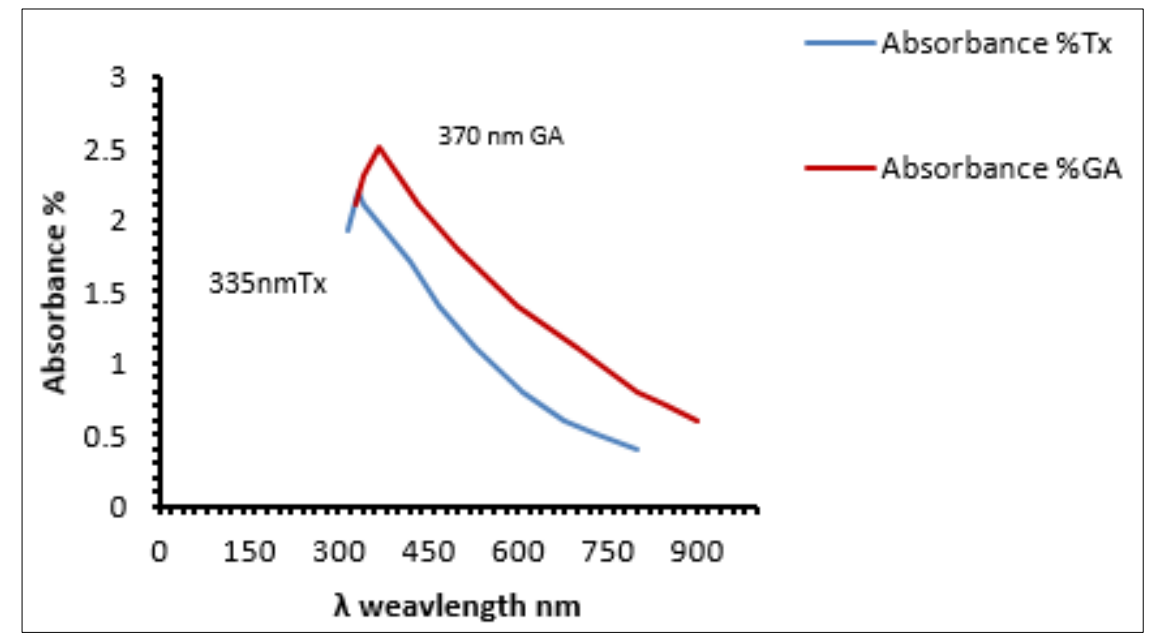

Figure 3. UV-VIS spectrum of of $\mathrm{ZnO} / \mathrm{EG}$ nanofluids with 0.5 vol.\% Gum Arabic and Tx-100 just after preparation

After 60 days of storage an another spectrometry test was taken to the $\mathrm{ZnO} /$ ethylene glycol nanofluids showing that the wavelength of absorption peaks was shifted at $380 \mathrm{~nm}$ and $355 \mathrm{~nm}$, respectively. This indicates the higher stability of nanofluids with GA surfactant addition than with Tx-100 for the same concentration, as shown in Figure 4.

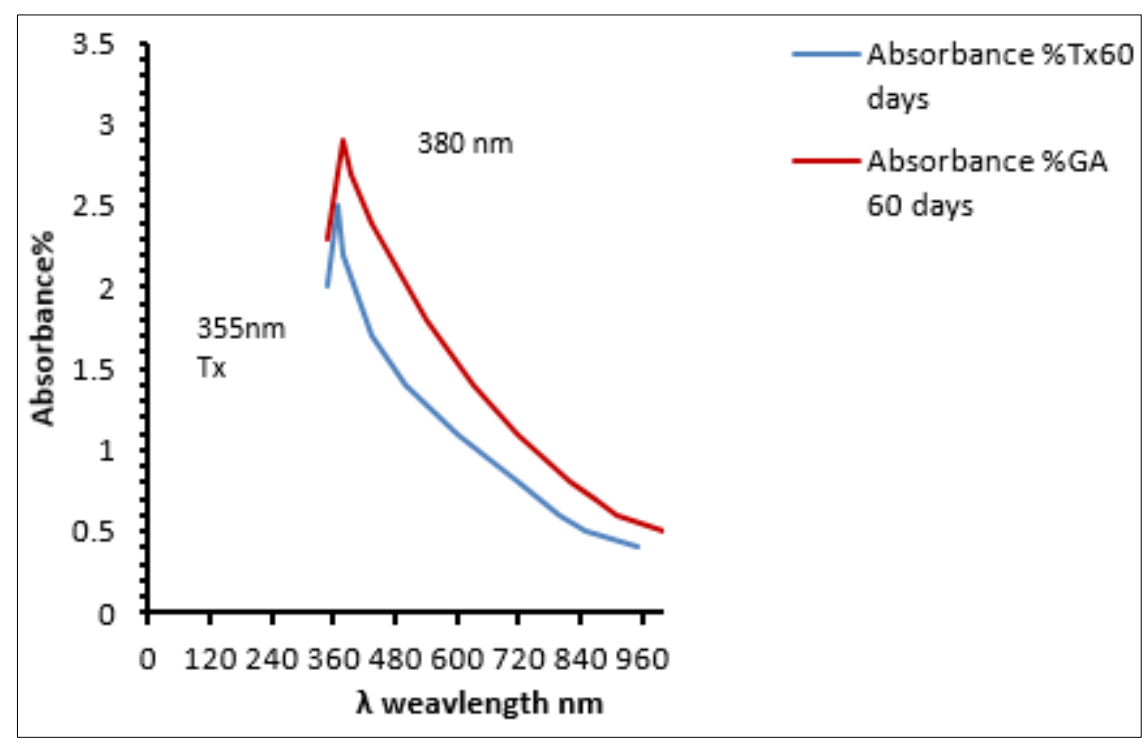

Figure 4. UV-Vis spectrum of $\mathrm{ZnO} / \mathrm{EG}$ nanofluids with 0.5 vol.\% Gum Arabic and Tx-100 after 60 days storage

\subsection{Thermal conductivity coefficient}

The thermal conductivity represents the most important parameter factor to save thermal energy in any system[19]. We measured thermal conductivity coefficient of simple $\mathrm{ZnO}$ / ethylene glycol mixtures of different concentrations, and then with addition of surfactants Gum Arabic and Tx-100. The results showed that the thermal conductivity coefficient of $\mathrm{ZnO}$ / ethylene glycol simple suspension enhanced when zinc oxide nanoparticles fraction in the mixture increased as shown in Figure 5, this being in agreement with results of other authors [20-22]. 


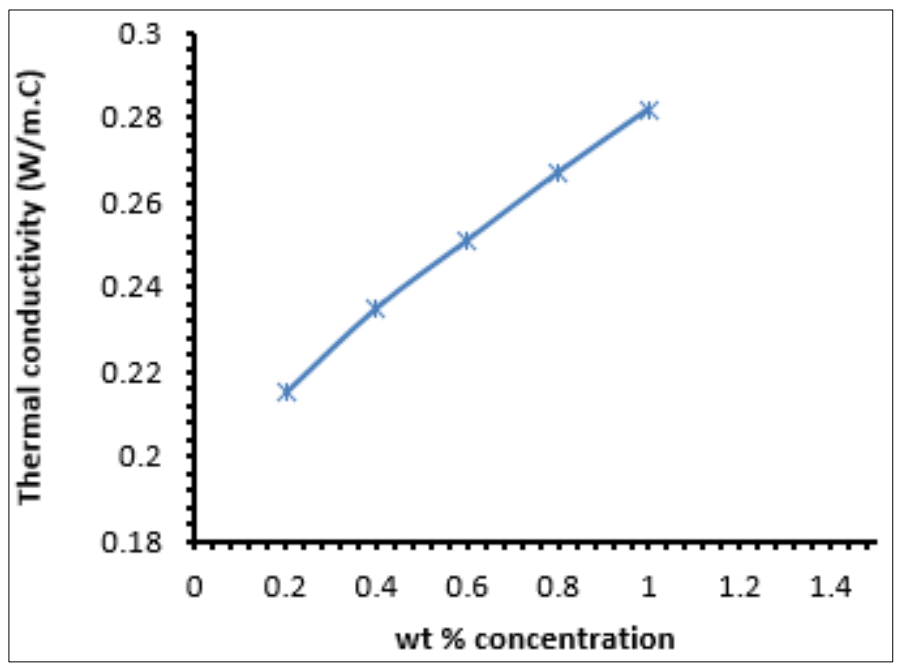

Figure 5. Thermal conductivity coefficient of simple $\mathrm{ZnO} / \mathrm{EG}$ nanofluids at different $\mathrm{ZnO}$ concentrations

Figure 6 shows the values of thermal conductivity coefficient with addition of surfactants Gum Arabic and Tx-100. The results revealed that this parameter of $\mathrm{ZnO} / \mathrm{EG}$ with Gum Arabic stabilizer has higher values compared to the thermal conductivity of ZnO/EG containing Tx-100 surfactant. This behavior suggests a higher stability of $\mathrm{ZnO} / \mathrm{EG}$ nanofluids with Gum Arabic. The results also agreed with values obtained by other authors [23-25].

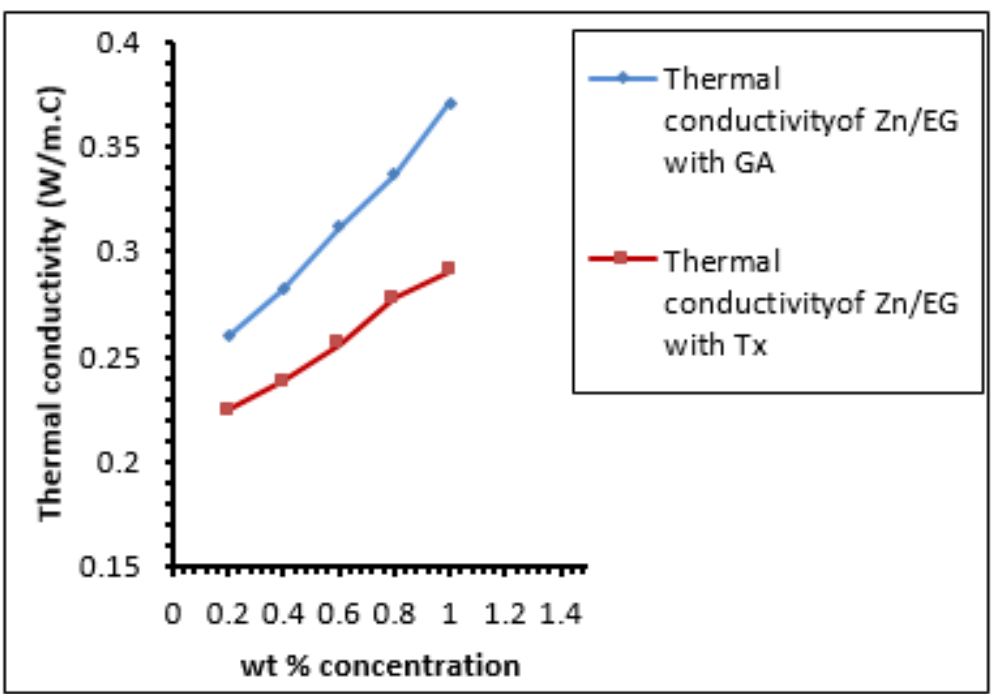

Figure 6. Thermal conductivity coefficient of $\mathrm{ZnO} / \mathrm{EG}$ nanofluids containing Gum Arabic (GA) and Tx-100 with different stabilizer concentrations

\section{Conclusions}

Taking into account that the stability of nanofluids with solid particles content is one of the most important factors to ensure the most benefit of their properties, the stability of prepared $\mathrm{ZnO} / \mathrm{EG}$ nanofluids was measured by two ways, determining the zeta potential and wavelength of absorption peaks in UV-Vis spectra. The results revealed that Gum Arabic stabilizer showed larger stability compared to the Tx-100 in the $\mathrm{ZnO} / \mathrm{EG}$ nanofluids. The determined values of thermal conductivity coefficient of prepared nanofluids with addition of surfactants indicated that the thermal conductivity may increase up to $35 \%$ compared to the $\mathrm{ZnO} / \mathrm{EG}$ without surfactants. 


\section{References}

1.XIE, H., WANG, J., XI, T., LIU, Y., AI, F., WU, Q., Thermal conductivity enhancement of suspensions containing nanosized alumina particles, J. Appl. Phys., 91, 2002, 4568-4572.

https://doi.org/10.1063/1.1454184

2.MURSHED, S.M.S., LEONG, K.C., YANG, C., Enhanced thermal conductivity of $\mathrm{TiO}_{2}-$ Water based nanofluids, Int. J. Therm. Sci., 44, 2005, 367-373.

https://doi.org/10.1016/j.ijthermalsci.2004.12.005

3.COLANGELO, G., FAVALE, E., DE RISI, A., LAFORGIA, D., Results of experimental investigations on the heat conductivity of nanofluids based on diathermic oil for high temperature applications, Appl. Energy., 97, 2012, 828-833. https://doi.org/10.1016/j.apenergy.2011.11.026

4. MILANESE, M., IACOBAZZI, F., COLANGELO, G., DE RISI, A.:, An investigation of layering phenomenon at the liquid-solid interface in $\mathrm{Cu}$ and $\mathrm{CuO}$ based nanofluids, Int. J. Heat Mass Transf., 103, 2016, 564-571. https://doi.org/10.1016/j.ijheatmasstransfer.2016.07.082

5.COlAngelo, G., FAVAlE, E., MiglieTtA, P., MilaneSE, M., DE RISI, A., Thermal conductivity, viscosity and stability of $\mathrm{Al}_{2} \mathrm{O}_{3}$-diathermic oil nanofluids for solar energy systems, Energy, 95, 2016, 124-136.https://doi.org/10.1016/j.energy.2015.11.032

6.COlAnGElO, G., FAVAlE, E., MILANESE, M., STARACE, G., DE RISI, A., Experimental Measurements of $\mathrm{Al}_{2} \mathrm{O}_{3}$ and $\mathrm{CuO}$ Nanofluids Interaction with Microwaves, J. Energy Eng., 143, 2017, 1-7. https://doi.org/10.1061/(ASCE)EY.1943-7897.0000400

7.BOUGUERRA, N., PONCET, S., ELKOUN, S., Dispersion regimes in alumina/water-based nanofluids: Simultaneous measurements of thermal conductivity and dynamic viscosity, Int. Commun. Heat Mass Transf., 92, 51-55, 2018. https://doi.org/10.1016/j.icheatmasstransfer.2018.02.015

8.IACOBAZZI, F., MIlANESE, M., COLANGElO, G., LOMASCOLO, M., DE RISI, A., An explanation of the $\mathrm{Al}_{2} \mathrm{O}_{3}$ nanofluid thermal conductivity based on the phonon theory of liquid, Energy, 116, 2016, 786-794. https://doi.org/10.1016/j.energy.2016.10.027

9. HWANG, Y., LEE, J.K., LEE, J.K., JEONG, Y.M., CHEONG, S. IR, AHN, Y.C., KIM, S.H., Production and dispersion stability of nanoparticles in nanofluids, Powder Technol., 186, 2008, 145153. https://doi.org/10.1016/j.powtec.2007.11.020

10. KANADE, K.G., KALE, B.B., AIYER, R.C., DAS, B.K., Effect of solvents on the synthesis of nano-size zinc oxide and its properties, Mater. Res. Bull., 41, 2006, 590-600.

https://doi.org/10.1016/j.materresbull.2005.09.002

11. LUCIANI, G., IMPARATO, C., VITIELLO, G., Photosensitive hybrid nanostructured materials: The big challenges for sunlight capture, Catalysts, 10(1), 2020, 103.

12. CHAUDHURI, R.G., PARIA, S., Synthesis of sulfur nanoparticles in aqueous surfactant solutions, J. Colloid Interface Sci., 343, 2010, 439-446 (). https://doi.org/10.1016/j.jcis.2009.12.004

13. SAFAEI-NAEINI, Y., AMINZARE, M., GOLESTANI-FARD, F., KHORASANIZADEH, F., SALAHI, E., Suspension stability of Titania nanoparticles studied by UV-VIS spectroscopy method, Iran. J. Mater. Sci. Eng., 9, 2012,62-68.

14. ZAID, H.M., AHMAD LATIFF, N.R., YAHYA, N., The effect of zinc oxide and aluminum oxide nanoparticles on interfacial tension and viscosity of nanofluids for enhanced oil recovery, Adv. Mater. Res., 1024, 2014, 56-59. https://doi.org/10.4028/www.scientific.net/AMR.1024.56

15.ANAND, K., VARGHESE, S., Role of surfactants on the stability of nano-zinc oxide dispersions, Part. Sci. Technol., 35, 2017,67-70. https://doi.org/10.1080/02726351.2015.1131787

16.NURDIN, I., ZULKIFLI, SATRIANANDA, NURLAILI, The Study of Gum Arabic as Surfactant on the Stability of Water-based Alumina Nanoparticle Suspensions. IOP Conf. Ser. Mater. Sci. Eng. 536, 6-12 (2019). https://doi.org/10.1088/1757-899X/536/1/012086

17. PAUZI, N., ZAIN, N.M., YUSOF, N.A.A., Gum arabic as natural stabilizing agent in green synthesis of $\mathrm{ZnO}$ nanofluids for antibacterial application, J. Environ. Chem. Eng., 8(3), 2020, 103331 
18.ESTRADA-URBINA，J., CRUZ-ALONSO，A., SANTANDER-GONZÁLEZ，M., MÉNDEZALBORES, A., VÁZQUEZ-DURÁN, A., Physiological and sanitary quality of a Mexican landrace of red maize, Nanomaterials, 8, 2018, 1-12. https://doi.org/10.3390/nano8040247

19.DE OLIVEIRA, L.R., RIBEIRO, S.R.F.L., REIS, M.H.M., CARDOSO, V.L., BANDARRA FILHO, E.P., Experimental study on the thermal conductivity and viscosity of ethylene glycol-based nanofluid containing diamond-silver hybrid material, Diam. Relat. Mater., 96, 2019, 216-230.

https://doi.org/10.1016/j.diamond.2019.05.004

20. LI, H., WANG, L., HE, Y., HU, Y., ZHU, J., JIANG, B., Experimental investigation of thermal conductivity and viscosity of ethylene glycol based $\mathrm{ZnO}$ nanofluids, Appl. Therm. Eng., 88, 2015, 363368.

21.KOLE, M., DEY, T.K., Effect of prolonged ultrasonication on the thermal conductivity of ZnOethylene glycol nanofluids, Thermochim. Acta, 535, 2012, 58-65.

22. SIMPSON, S., SCHELFHOUT, A., GOLDEN, C., VAFAEI, S., Nanofluid thermal conductivity and effective parameters, Appl. Sci., 9(1), 2018, 87.

23.INDHUJA, A., SUGANTHI, K.S., MANIKANDAN, S., RAJAN, K.S., Viscosity and thermal conductivity of dispersions of gum arabic capped MWCNT in water: Influence of MWCNT concentration and temperature, J. Taiwan Inst. Chem. Eng., 44, 2013, 474-479.

https://doi.org/10.1016/j.jtice.2012.11.015

24. AKBARI, A., ALAVI FAZEL, S.A., MAGHSOODI, S., SHAHBAZI KOOTENAEI, A., Thermophysical and stability properties of raw and functionalization of graphene nanoplatelets-based aqueous nanofluids, J. Dispers. Sci. Technol., 40, 2019, 17-24. https://doi.org/10.1080/01932691.2018.1462713 25.ALIAS, H., ANI, M.F.C., Thermal characteristic of nanofluids containing titanium dioxide nanoparticles in ethylene glycol, Chem. Eng. Trans., 56, 2017, 1459-1464.

Manuscript received:28.06.2020 